\title{
ECONOMIC INDICATORS AND HOUSING DEVELOPMENT: REGIONAL BASED EXPLORATORY ANALYSIS IN TURKEY
}

\author{
EKONOMIKK GÖSTERGELER VE KONUT SEKTÖRÜ GELISŞIMII: \\ TÜRKIYYE ÖRNEĞINIIN BÖLGE ÖLÇEĞİNDE ANALIZŻ
}

\author{
Elif ALKAY \\ Craig WATKINS ${ }^{* *}$ \\ Gökhan ÖVENÇ⿻*
}

\begin{abstract}
The relationship between economic growth and housing construction sector activity has been under scrutiny internationally for more than five decades. This study seeks to add to this literature by exploring the economic drivers of housing construction activity in Turkey. The case study is important for three reasons: first, this analysis is one of the rare studies to have been undertaken in an emerging market context; second, as in many global markets, there is considerable spatial variation in activity across the country and, in a manner that is replicable for European markets, we have addressed this phenomena by combining insights generated by undertaking analysis at different spatial scales (NUTS levels); third, we offer a strategy that might be replicated elsewhere for measuring construction activity in the absence of housing starts and completion data. The results of our analysis suggest that rather than being a function of uneven economic growth, much of the variation in construction activity might actually be a consequence of land use regulation, proactive planning and other public policy interventions at local and national level.
\end{abstract}

Keywords: Housing construction activity, residential building permits, economic indicators, Turkey

JEL Classification: R11, R31, L74

Özet

Ekonomik göstergeler ve konut sektörünün gelişimi arasındaki ilişki özellikle son elli yıldır araştırmacıların dikkatini çekmekte ve çalışmalara konu olmaktadır. Bu çalışma, ilgili literature,

Associate Prof, Istanbul Technical University, Department of Urban and Regional Planning, Taksim-Istanbul, Turkey, Corresponding Author, alkayel@itu.edu.tr, Orcid Id: 0000-0001-6030-9219

* Prof, University of Sheffield, Department of Urban Studies and Planning, Sheffield, UK, c.a.watkins@sheffield.ac.uk, Orcid Id: 0000-0002-1249-9473

*** Assistant Prof, Istanbul University, Faculty of Economics, Department of Economics (English), Beyazit-Istanbul, Turkey, gokhanovenc@istanbul.edu.tr, Orcid Id: 0000-0003-4632-9760 
Türkiye'de konut sektörü ve ekonomik göstergeler arasındaki ilişkiyi mekansal bazda ortaya koyarak katkıda bulunmayı amaçlamaktadır. Türkiye örneği üç nedenle önem kazanmaktadır: İlk olarak, gelişmekte olan ülkeler kümesinde yer alan Türkiye örneğinde sosyo-ekonomik göstergeler ve konut sektörü mekansal gelişimi arasındaki ilişkinin analizi ilgili literatüre Türkiye örneğiyle katkı sunacaktır. İkinci olarak, konut sektörünün mekansal gelişimi heterojen bir yapı göstermektedir. Heterojen gelişmeye neden olan unsurların analizi bu yapısal durumun farklı mekansal ölçeklerde nasıl gerçekleştiğini anlamanın yanı sıra politika geliştirme süreçlerine katkıda bulunacaktır. Bu bağlamda, bu çalışmada mekansal farklılaşma üç farklı istatistiki bölge düzeyinde analiz edilmiş ve mekansal farklılaşmanın yansıtılmasında hem analiz ölçeğinin hem de yerel düzeyde politika geliştirmenin önemi ortaya konmuştur. Son alarak, çalışma, başlanan ve bitirilen konut inşaatı sayısını gösteren verinin olmadığı durumlarda, konut inşaat izin istatistiklerinin kullanılması yoluyla sektör ve temel ekonomik göstergeler arasındaki ilişkinin analiz edilebileceğini gösteren örnek bir çalışmadır. Üç farklı NUTS bölgesi düzeyinde yapılan analiz sonuçları göstermektedir ki konut sektörünün gelişmişlik düzeyi bölgelerin ekonomik gelişmişlikler yanı sıra planlama ve arsa ve arazi politikaları ile yerel ve ulusal düzeyde kamu yatırımlarından etkilenmektedir.

Anahtar Kelimeler: Konut inşaat sektörü, konut inşaat izni, ekonomik göstergeler, Türkiye

JEL Sınıflandırması: R11, R31, L74

\section{Introduction}

There is a long-standing international literature that seeks to explain both spatial and temporal variations in housing construction activity ${ }^{1}$. This applied research points to the influence of a variety of social and economic drivers of construction activity and applies a range of statistical and econometric modelling techniques to help understand the causal relationships between housing and the economy and the relative importance of various factors in different institutional settings.

There are two main limitations in the existing literature that we seek to address here. First, most of the existing empirical research on this topic focuses on case study areas that real estate analysts would tend to classify as mature markets. There is a relative lack of analysis of emerging markets, even though it has long been recognised that these are likely to have different structural characteristics and follow different dynamic paths ${ }^{2}$. This paper seeks to address this by looking at evidence from Turkey. The contribution of construction sector to national GDP averaged 6 per cent between 1998 and 2014. Data from between 2002 and 2014 shows a positive and strong correlation (0.84) between economic growth and the growth of the construction sector in Turkey ${ }^{3}$. The employment capacity of the sector is significant, making up 5.6\% of the total employment in 2005 , and growing to $7.3 \%$ by $2014^{4}$. In the recent past, both national and local policy makers in

1 See Maisel for an early contribution, MAISEL, S.J. (1963). A Theory of Fluctuations in Residential Construction Starts, The American Economic Review, 53(3), 359-383.

2 KEOGH, G., D’Archy, E. (1999). Property Market Efficiency: An Institutional Economics Perspective, Urban Studies, 36(13), 2401-2414.

3 TUIK (Türkiye İstatistik Kurumu), (2014a). Illere Gore Insaat Izin Istatistikleri, Haziran 2014 (Veri TUIK den satin alinmistir); TUIK (Türkiye İstatistik Kurumu), (2015a). İstatistiksel Tablolar, Üretim Yöntemi ile GSYH, Sabit Fiyatlarla GSYH, Faaliyet Kollarına Göre GSYH, Temmuz 2015, http://www.tuik.gov.tr/PreTabloArama.do

TMB (Turkiye Muteahhitler Birligi) (2015). Insaat Sektoru Analizi Bulteni, 2015/Temmuz, Ankara. 
Turkey have prioritised construction activity as a central feature of economic growth strategies. This has been underpinned by public investment in infrastructure. This strategy, which is common in many emerging market contexts, has had interesting yet untested impacts on the rate and spatial pattern of development activity. Interestingly, in this context, Alkay et al ${ }^{5}$ hypothesise that proactive planning and local economic development policy interventions might arguably be causing a break between economic fundamentals and construction sector activity at local and national levels. Thus, given the market and policy context, Turkey offers useful lessons for analysts and policy makers working in other emerging market contexts.

Second, most of the existing studies tend to focus on aggregate, national level data. As a result, much of this analysis tends to underplay the importance of what are often quite significant spatial differences in construction activity between municipalities and regions. This research seeks to address this weakness by analysing data at three different spatial scales, namely NUTS 1, 2 and 3 levels, over the period between 2004 and 2014. Although the social and economic indicators available at these levels vary, the modelling strategy adopted here allows us to reflect on the cumulative insights from the three sets of models.

In most studies of construction activity, analysts use either housing starts or housing completions as the key measure of activity levels. Starts are often criticised as, in some contexts and in times of recession, not all projects that begin reach completion. Completions data, while generally viewed as more reliable, tend to lag economic indicators by large and varied margins due to the complexity of the development process. The need to accurately accommodate complex lag structure adds to the challenging nature of the modelling process and is made more difficult in emerging market studies where time-series tend to be quite short. To compound these issues, these data are not readily available in many markets. To overcome, the paucity of the data on housing starts and completions, this paper analyses the volume of residential building permits. Again, there are weaknesses with this data source, not least the possibility that not all permits granted are translated into projects and completions. But, following Henneberry et $\mathrm{al}^{6}$ and Bramley and Watkins ${ }^{7}$ who also use measures based on the permission to build, the view here is that these data providing a useful starting point from which to understand the relationship between the economy and housing development and that they might be used more widely as long as, in line with normal scientific practice, appropriate caveats are added to the conclusions drawn.

The paper is developed in three further sections. The next section reviews the existing international literature on the relationship between economic indicators and construction activity. The review is used to identify potential explanatory variables and methods that might be used in the applied analysis of the Turkish housing construction sector. Section three provides an overview of the

5 ALKAY, E., Watkins, C. \& Keskin, B. (2018). Explaining Spatial Variation in Housing Construction Activity in Turkey, International Journal of Strategic Property Management, 22(2), 119-130, https://doi.org/10.3846/ijspm.2018.443

6 HENNEBERRY, J., McGough, T., Mouzakis, F (2005). “Estimating the Impact of Planning on Commercial Property Markets" in Adams, D, Watkins, C and White, M (Eds) Planning, Public Policy and Property Markets, Oxford: Blackwells

7 BRAMLEY, G., Watkins, C. (1995) Steering the Housing Market, Bristol, Policy Press. 
research design and data used; reflects the models developed draw on the factors shown to be important in the international literature and in the stylised account of Turkish market dynamics; outlines the model results at each spatial level. The concluding section offers some broader reflections and through on the future research agenda.

\section{Modelling the Relationship between Economic Growth and Housing Construction Activity}

Construction sector activity both drives economic growth and is driven by it. The potential to use construction activity to underpin growth has long held appeal to policy makers, while understanding the impact of growth on building levels has been of critical interest to market analysts. This had led to the development of a voluminous literature that looks at various different aspects of the two-way relationship ${ }^{8}$. Key contributions to the literature focus on the employment impacts of development ${ }^{9}$; others attempt to assess the role of the construction sector and economic growth in economies at different stages of the business cycle ${ }^{10}$, while others seek to model the causal forward links from construction ${ }^{11}$. This literature provides useful insights into alternative modelling strategies and offers a clear steer on what variables might helpfully be included in models using Turkish data.

8 For further discussions see, POLENSKE, K.R., Sivitanides, P. (1990). Linkages in the construction sector, The Annals of Regional Science, 24, 147-161; BIELSA, J., Duarte, R. (2011). Size and linkages of Spanish construction industry: key sector or deformation of the economy? Cambridge Journal of Economics, 35, 317-334; BON, R., Birgönül, T. \& Özdoğan, İ. (1999). An input-output analysis of the Turkish construction sector, 1973-1990: a note, Construction Management and Economics, 17(5), 543-551; KOFOWOROLA, O.F., Gheewala, S. (2008). An input-output analysis of Thailand construction sector, Construction Management and Economics, 26, 1227-1240; PIETROFORTE, R., Bon, R. (1995). An input-output analysis of the Italian construction sector, 1959-1998, Construction Management and Economics, 13, 253-262; SONG, Y., Liu, C., Langston, C. (2006). Linkage measures of the construction sector using the hypothetical extraction method, Construction Management and Economics, 24, 579-589; ILHAN, B., Yaman, H. (2011). A comparative input-output analysis of the construction sector in Turkey and EU countries, Engineering, Construction and Architectural Management, 18(3), 248-265.

9 WELLS, J., Wall, D. (2003). The expansion of employment opportunities in the building construction sector in the context of structural adjustment: some evidence from Kenya and Tanzania, Habitat International, 27, 325-337.

10 See, GIANG, D.T.H., Pheng, L.S. (2011). Role of construction in economic development: Review of key concepts in the past 40 years, Habitat International, 35, 118-125; OFORI, G. (2001). Indicators for measuring construction industry development in developing countries, Building Research and Information, 29(1), 40-50; CHOW, G.C. (1993). Capital formation and economic growth in China, The Quarterly Journal of Economics, 108(3), 809-842; MALLICK, H. \& Mahalik, M.K. (2010). Constructing the economy: the role of construction sector in India's growth, Journal of Real Estate Finance Economy, 40, 368-384; PIETROFORTE, R., Gregori, T. (2003). An input-output analysis of the construction sector in highly-developed economies, Construction Management and Economics, 21, 319-327; RUDDOCK, L., Lopes, J. (2006). The construction sector and economic development: the 'Bon curve', Construction Management and Economics, 24, 717-723; SU, C-K., Lin, C-Y., Wang, M-T. (2003). Taiwanese construction sector in a growing 'maturity' economy, 1964-1999. Construction Management and Economics, 21, 7, 719-728; WELLS, J. (2001). Construction and capital formation in less developed economies: unravelling the informal sector in an African city, Construction Management and Economics, 19(3), 267-274.

11 See, CHANG, T., Nieh, C.C. (2004). A note on testing the causal link between construction activity and economic growth in Taiwan, Journal of Asian Economics, 15, 591-598; OZKAN, F., Ozkan, O., Gunduz, M. (2012). Causal relationship between construction investment policy and economic growth in Turkey, Technological Forecasting \& Social Change, 79, 362-370. 
For instance, Rahman and Mustafa ${ }^{12}$, use vector cointegration analysis to illustrate that there are complex two-way relationship between real estate activity and the wider economy. They show that US housing starts both help to drive changes in real Gross Domestic Product and are driven by national output growth. The analysis, which draws on data from between 1960 and 1993, also shows that levels of real consumer debt and changes in the long-term interest rate, which can indicate likely changes to demand levels, have an important impact on construction activity.

The findings are consistent with those of Topel and Rosen ${ }^{13}$ who also explore aggregate data for the US and demonstrate that investment in housing development activity is driven by wider economic conditions. Specifically they use real income rather than GDP as a proxy for growth. They also show that lagged price changes and construction costs are important, given that individually and in combination they impact on expectations about development profits.

Ewing and Wang ${ }^{14}$ apply different methods, ARIMA, Vector Error Correction Models, and Generalised Impulse Response functions in attempt to understand the macroeconomic influences on US housing starts. Using data from between 1981 and 2001, they show that starts are inversely related to inflation, as measured by the Consumer price index, as well as real output and real interest rates.

Several other studies place greater weight on the importance of credit availability and mortgage finance. Puri and Van Lierop ${ }^{15}$, for instance, develop an econometric model with a stock-flow structure that illustrates the crucial importance of the cost and availability of credit on the volume of housing starts. These results are supported by those of Thom ${ }^{16}$ who develops a four variable VAR model that shows that interest rates and mortgage availability were highly significant in shaping US housing starts between 1967 and 1984.

Some of these findings also resonate with those from a later cross-sectional study by Mayer and Tsuriel Sommerville ${ }^{17}$ who show that planning permission for single-family homes, which is used as a proxy for new housing activity, is influenced by interest rates and lagged house price growth. The study, which focuses on data from different planning jurisdictions rather than national level data, also shows that demographic factors, a key driver of household growth and housing demand, also influence planning applications and permissions. More importantly it also illustrates the importance of policy regimes and finds that the time taken to make planning decisions, the restrictiveness of development control regime, and the level of development fees

12 RAHMAN, M., Mustafa, M. (1997). Growth in US housing starts, real consumer depth, real GDP and the long-term real interest rate: a vector cointegration analysis, Applied Economic Letters, 4, 757-759.

13 TOPEL, R., Rosen, S. (1988). Housing investment in the United States, Journal of Political Economy, 96(4), 718-740.

14 EWING, B.T., Wang, Y. (2005). Single housing starts and macroeconomic activity: an application of generalized impulse response analysis, Applied Economic Letters, 12, 187-190.

15 PURI, A.K., Van Lierop, J. (1988). Forcasting housing starts, International Journal of Forecasting, 4(1), $125-134$.

16 THOM, R. (1985). The Relationship between Housing Starts and Mortgage Availability, The Review of Economics and Statistics, 67(4), 693-696.

17 MAYER, C.J., Tsuriel Somerville, C. (2000). Land use regulation and new construction, Regional Science and Urban Economics, 30, 639-662. 
have significant impacts. There is further evidence that political and institutional structures matter elsewhere in the literature. Huang ${ }^{18}$, for instance, provides evidence that the atomistic structure of the industry and the tendency for builders to engage in speculative activity can have a large impact on the level of construction activity.

The development of the literature that seeks to understand the relationship between housing activity and wider economic and policy influences has been constrained by the absence of data. While there are forecasts of housing starts for Japan and Canada as well as the US ${ }^{19}$, the lack of availability of reliable measures is a problem in many countries, especially in emerging and transitional market contexts. Stevenson et $\mathrm{al}^{20}$ offer a useful alternative to the use of housing starts or completion data. They undertake a socio-spatial analysis of building permits as a means of understanding the rate and pattern of new construction activity in Mississippi as it sought to recover from Hurricane Katrina.

The main gap in the econometric analysis is the failure to take account of the role of institutional structures and policy interventions ${ }^{21}$. Specifically, the models do not readily accommodate the impacts new models of innovation on the operation of the sector, its productivity or wider socioeconomic benefits ${ }^{22}$. They also fail to capture the impact of changes in institutional frameworks that might also lead to enhance efficiency and improved outcomes ${ }^{23}$. In terms of policy influence, systems approaches to policy and development planning and strategic planning can influence sector activity ${ }^{24}$.

18 HUANG, D.S. (1973). Short-Run Instability in Single-Family Housing Starts, Journal of the American Statistical Association, 68(344), 788-792.

19 See, PIERDZIOCH, C., Rülke, J.C., Stadmann, G. (2012). Housing Starts in Canada, Japan, and the United States: Do Forecasters Herd?, The Journal of Real Estate Finance and Economics, 45(3), 754-773.

20 STEVEnSON, J.R., Emrich, C.T., Mitchell, J.T., Cutter, S.L. (2010). Using Building Permits to Monitor Disaster Recovery: A Spatio-Temporal Case Study of Coastal Mississippi Following Hurricane Katrina, Cartography and Geographic Information Science, 37(1), 57-68.

21 For further discussion see, ADAMS, D and Watkins, C (2015) The Value of Planning, London: RTPI; ELINWA, A.U., Joshua, M. (2001). Time-overrun factors in Nigerian construction industry, Journal of Construction Engineering and Management, 127(5), 419-425.

22 See, SLAUGHTER, E.S. (1998). Models of construction innovation, Journal of Construction Engineering and Management, 124(3), 226-231; RUDDOCK, L., Ruddock, S. (2009). Reassessing productivity in the construction sector to reflect hidden innovation and the knowledge economy, Construction Management and Economics, 27, 871-879; WHYTE, J. (2003). Innovation and users: virtual reality in the construction sector, Construction Management and Economics, 21, 565-572; BLAYSE, A.M., Manley, K. (2004). Key influences on construction innovation, Construction Innovation, 4, 143-154.

23 See, MAYO, R.R., Liu, G. (1995). Reform agenda of Chinese construction industry, Journal of Construction Engineering and Management, 121(1), 80-85; JENSEN, J.S., Gottlieb, S.C., Thuesen, C.L. (2011). Construction sector development: frames and governance responses, Building Research and Information, 39(6), 665-667; POSNER, R. (1998). Creating a legal framework for economic development, The World Bank Research Observer, 13(1), 1-11.

24 See, ÖNER, M.A., Sarıtaş, Ö. (2005). A systems approach to policy analysis and development planning: Construction sector in the Turkish 5-year development plans, Technological Forecasting \& Social Change, 72, 886-911; OFORI, G. (1994). Formulating a long-term strategy for developing the construction industry of Singapore, Construction Management and Economics, 12, 219-231; WONG, J.M.W., Ng, S.T., Chan, A.P.C. (2010). Strategic planning for the sustainable development of the construction industry in Hong Kong, Habitat International, 34, 256-263. 
Taken together, this literature offers different approaches to measuring construction activity, which includes the use of data on housing starts, housing completions, planning permissions, or building permits. It also points to numerous potential drivers of construction activity including GDP growth, interest rates, consumer price inflation, consumer debt, credit availability, construction costs, population change, as well as policy interventions including growth management strategies, and development fee regimes and industry structure and behaviour. The applied research reported in this paper seeks to build on and extend this literature by exploring the extent to which several of these variables might be influencing development activity, as measured by residential building permits, in Turkey.

\section{Research Design, Data and Model Estimation}

The definition of statistical areas in Turkey follows the NUTS classification (Nomenclature of territorial units for statistics). Turkey includes 12 NUTS1 regions that are major socio-economic regions. NUTS2 regions are basic regions for the implementation of regional policies and there are 26 NUTS2 regions in Turkey. NUTS3 regions are provinces for specific diagnoses and our study area comprises 81 provinces. The relationship between housing construction sector activity and economic indicators is investigated empirically at those three different geographical scales.

The dependent variable is the number of residential building permits granted in the year. Data on residential building permits show the additions to the housing stock. This data reveals a striking increase between 2002 and 2013, with a total of 924,341 building permits granted between 2002 and 2013 . Of these, $86.37 \%(793,413)$ are residential building permits ${ }^{25}$.

The independent variables base on the literature discussed above but not all measures are available at all levels. At NUTS1 level, the distribution of annual household disposable incomes by quintiles; at NUTS2 level, gross value added; at NUTS3 level, total public expenditures, population and total bank credits are included as explanatory variables. Table 1 summarises the variables used in the model estimations. As seen from the Table 1, 3 different time periods are used for each NUTS levels since only these data (time series) were available together during the research period. The intersection sets of time series were chosen to run the model ${ }^{26} 2728$. In line with standard practice, prior to estimating the models, autocorrelation and heteroscedasticity tests are undertaken and appropriate adjustments made. All the models are estimated using fixed effects and by employing STATA 13.

25 TUIK (Türkiye İstatistik Kurumu), (2014a). Illere Gore Insaat Izin Istatistikleri, Haziran 2014 (Veri TUIK den satin alinmistir).

26 TUIK (Türkiye İstatistik Kurumu), (2015b). İstatistiksel Tablolar, Gelir İstatistikleri, Temmuz 2015, http://www.tuik. gov.tr/PreTabloArama.do

27 TUIK (Türkiye İstatistik Kurumu), (2014b). İstatistiksel Tablolar, Yıllara Göre İl Nüfusları, http://tuik.gov.tr/ PreTablo.do?alt_id=1059

28 TUIK (Türkiye İstatistik Kurumu), (2015c). İstatistiksel Tablolar, Bölgesel Hesaplar, Bölgesel Gayrisafi Katma Değer, Temmuz 2015, http://www.tuik.gov.tr/PreTabloArama.do 
Two models are estimated for each geographical scale: the first of these entered just the key variables, while the second also included NUTS level region dummy variables. The latter is estimated to investigate each region contribution to housing sector development and to explore the extent to which regional impacts might significantly differ from each other ${ }^{29}$. As Istanbul is defined as a single region in any NUTS level classification, it is therefore employed as a comparison region meaning that all parameter estimates need to be interpreted in contrast with Istanbul. Moreover, residual analysis, at each NUTS level, exposed on maps bases on the second model and reflects the regional impacts on housing sector development in contrast with İstanbul (see Figure 1, 2 and 3). Due to data limitations the specification of the equations at each level is never ideal but that, when taken together the results do provide a reliable overview of the relationship between economic indicators and construction activity across the country.

Table I: Model variables at NUTSI, NUTS2 and NUTS3 level

\begin{tabular}{|c|c|c|c|c|c|c|c|c|c|}
\hline & Variable & Variable definition & Time & Mean & St.dev & Min. & Max. & Source & $\begin{array}{l}\text { Measurement } \\
\text { unit }\end{array}$ \\
\hline \multirow{3}{*}{ 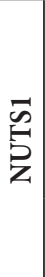 } & logpermit & $\begin{array}{l}\text { Residential buildings } \\
\text { permit numbers }\end{array}$ & $\begin{array}{l}2006- \\
2013\end{array}$ & 8.348 & 0.946 & 6.056 & 10.065 & TUIK, 2014a & Natural log \\
\hline & logincome & $\begin{array}{l}\text { Annual household } \\
\text { disposable incomes } \\
\text { by quintiles }\end{array}$ & $\begin{array}{l}2006- \\
2013\end{array}$ & 10.389 & 0.277 & 9.532 & 11.094 & TUIK, 2015b & Natural log \\
\hline & Dummy1 & $\begin{array}{l}\text { If years } 2012 \text { and } \\
2013=1 \text {, otherwise }=0\end{array}$ & $\begin{array}{l}2012- \\
2013\end{array}$ & & & & & & \\
\hline \multirow{3}{*}{ 怘 } & logpermit & $\begin{array}{l}\text { Residential buildings } \\
\text { permit numbers }\end{array}$ & $\begin{array}{l}2004- \\
2011\end{array}$ & 7.326 & 1.093 & 4.262 & 9.246 & TUIK, 2014a & Natural log \\
\hline & $\operatorname{loggva}$ & Gross value added & $\begin{array}{l}2004- \\
2011\end{array}$ & 16.786 & 0.861 & 15.035 & 19.559 & TUIK, 2015c & Natural log \\
\hline & Year & Time & $\begin{array}{l}2004- \\
2011\end{array}$ & & & & & & \\
\hline \multirow{5}{*}{ 苗 } & logpermit & $\begin{array}{l}\text { Residential buildings } \\
\text { permit numbers }\end{array}$ & $\begin{array}{l}2007- \\
2014\end{array}$ & 5.893 & 1.471 & 0 & 9.373 & TUIK, 2014a & Natural log \\
\hline & diogcredit & Total bank credits & $\begin{array}{l}2007- \\
2014\end{array}$ & 0.235 & 0.124 & -0.479 & 1.100 & TBB, 2015 & $\begin{array}{l}\text { Natural log } \\
\text { first difference }\end{array}$ \\
\hline & dloggovspnd & $\begin{array}{l}\text { Total government } \\
\text { spending }\end{array}$ & $\begin{array}{l}2007- \\
2014\end{array}$ & 0.143 & 0.055 & -0.210 & 0.408 & $\begin{array}{l}\text { Maliye } \\
\text { Muhasebat, } \\
2014\end{array}$ & $\begin{array}{l}\text { Natural log } \\
\text { first difference }\end{array}$ \\
\hline & $d \log p o p$ & Population & $\begin{array}{l}2007- \\
2014\end{array}$ & 0.008 & -0.018 & 0.100 & 0.109 & TUIK, 2014b & $\begin{array}{l}\text { Natural log } \\
\text { first difference }\end{array}$ \\
\hline & dummy3 & $\begin{array}{l}\text { If analysing city }=1 \text {, } \\
\text { otherwise }=0\end{array}$ & & & & & & & \\
\hline
\end{tabular}

29 See Karahasan's study for further discussion on unequal regional benefits from growth. KARAHASAN, B.C. (2015). Regional Inequalities in Turkey: Post 2001 Era, Marmara Üniversitesi, İ.̇̇.B. Dergisi, Cilt XXXVII, Say1 I, 125-147. Findings of this study may reflect parallelism with the empirical findings of our study that regional impacts on housing development sector is not random. 


\section{I. NUTS I Level Summary}

The NUTS1 level model covers 12 regions and uses data from the 2006-2013 period. The period is restricted between 2006 and 2013 since the disposable income by quintiles ended in 2013 when this research was started. The dependent variable is residential building permits and independent variable is the average disposable household income of the $4^{\text {th }}$ and $5^{\text {th }}$ quintiles. This two income groups is particularly included in the analysis by assuming them has a striking impact on the volume of the housing market. Since the measurement of variables are different and multiechelon, the natural logarithm of the variables is used. The variable graphs reveal a striking decrease in dependent variable in year 2012. In order to test whether this break point is econometrically significant, and helps increase the explanation power of the model, a year dummy variable is included in the estimation (see Equation 1).

$$
\begin{gathered}
\sum_{i=1}^{12} \sum_{t=2006}^{2013} y_{i, t}=A+B \sum_{i=1}^{12} \sum_{t=2006}^{2013} X_{i, t}+d_{t}+u_{i, t} \\
d_{t}=1 \text { if } \mathrm{t} \text { (year) } \geq 2012 ; 0 \text { otherwise. }
\end{gathered}
$$

Equation I: NUTSI level model

As noted above, our two models are estimated with and without region dummies (Table 2-3). The model without region dummies shows that year dummy designed to capture the break point in 2012 has a significant and negative impact on residential building permits ${ }^{30}$. All else equal, the $1 \%$ increase in disposable income of households of the highest two quintiles has increased the residential building permits by $0.5 \%$ in NUTS1 level model. This suggests, in line with theoretical expectations and other studies, that there is a strong positive relation between income levels, particularly high-income levels, and housing sector activity.

Table 2: NUTSI level model estimation-without dummies

\begin{tabular}{|l|l|l|l|l|ll|}
\hline Logpermit & Coef. & Std. Err. & Z & \multicolumn{2}{|l|}{ P>IzI } & [95\% Conf. Interval] \\
\hline logincome & 1.226706 & .151168 & 8.11 & 0.000 & .9304225 & 1.52299 \\
Dummy1 & -.2315179 & .0650084 & -3.56 & 0.000 & -.358932 & -.1041038 \\
cons & -4.202869 & 1.554708 & -2.70 & 0.007 & -7.25004 & -1.155697 \\
\hline
\end{tabular}

Notes: Coefficients: Generalized Least Squares; Panels: Heteroskedastic; Correlation: Common AR(1) coefficient for all panels (0.7334); Estimated Covariances: 12; Estimated Autocorrelations: 1; Estimated Coefficients: 3; Number of obs= 96; Number of groups $=12$; Time periods $=8$; Wald chi2 (2) $=65.86 ;$ Prob $>$ chi2 $=0.0000$

30 See Bahçekapll’’s study for further discussion about the year effect. BAHÇEKAPILI, C. (2015). Türkiye Ekonomisinde 2011 Sonrası Sinırlı Büyümenin Nedenleri Üzerine Bir Analiz, Marmara Üniversitesi, İ.̇̇.B. Dergisi, Cilt XXXVII, Sayı I, 111-124. 
Table 3: NUTSI level model estimation-with dummies

\begin{tabular}{|l|l|l|l|l|lc|}
\hline Logpermit & Coef. & Std. Err. & $\mathbf{z}$ & P>IzI & [95\% Conf. Interval] \\
\hline logincome & 0.961032 & 0.103049 & 9.330 & 0.000 & 0.759059 & 1.163005 \\
Dummy1 & -0.083259 & 0.047353 & -1.760 & 0.079 & -0.176069 & 0.009551 \\
TR2 & 0.538051 & 0.192407 & 2.800 & 0.005 & 0.160941 & 0.915161 \\
TR3 & 1.549891 & 0.193420 & 8.010 & 0.000 & 1.170796 & 1.928986 \\
TR4 & 0.924216 & 0.189128 & 4.890 & 0.000 & 0.553533 & 1.294900 \\
TR5 & 0.580012 & 0.187220 & 3.100 & 0.002 & 0.213067 & 0.946956 \\
TR6 & 1.172246 & 0.211141 & 5.550 & 0.000 & 0.758417 & 1.586076 \\
TR7 & 0.186966 & 0.194452 & 0.960 & 0.336 & -0.194152 & 0.568085 \\
TR8 & 0.230261 & 0.192762 & 1.190 & 0.232 & -0.147545 & 0.608068 \\
TR9 & -0.664451 & 0.199741 & -3.330 & 0.001 & -1.055936 & -0.272966 \\
TRA & -1.306264 & 0.237533 & -5.500 & 0.000 & -1.771820 & -0.840708 \\
TRB & -0.710047 & 0.211505 & -3.360 & 0.001 & -1.124590 & -0.295505 \\
TRC & -0.365756 & 0.204184 & -1.790 & 0.073 & -0.765948 & 0.034436 \\
cons & -1.789651 & 1.116015 & -1.600 & 0.109 & -3.977000 & 0.397698 \\
\hline
\end{tabular}

Notes: Estimated Covariances: 12; Estimated Autocorrelations: 1; Estimated Coefficients: 14; Number of obs=96; Number of groups $=12$; Time periods $=8$; Wald chi2 $(13)=2127.72 ;$ Prob $>$ chi $2=0.0000$

The version of NUTS1 level model that includes regional dummy variables suggests that there is significant spatial variation in the relationship. The disposable income of households in the highest two quintiles in Aegean (TR3), Mediterranean (TR6), and, East Marmara (TR4) regions have the strongest impact on residential building permit numbers. In these regions, the unit increase in average disposable income of the $4^{\text {th }}$ and $5^{\text {th }}$ quintiles affect the residential building permits more than is the case in Istanbul (see Figure 1).

Conversely, the average disposable income of households in the highest two quintiles in North East Anatolia (TRA) region has a significant negative impacts on residential building permits. This region has the lowest average values for both $4^{\text {th }}$ and $5^{\text {th }}$ quintiles in the country.

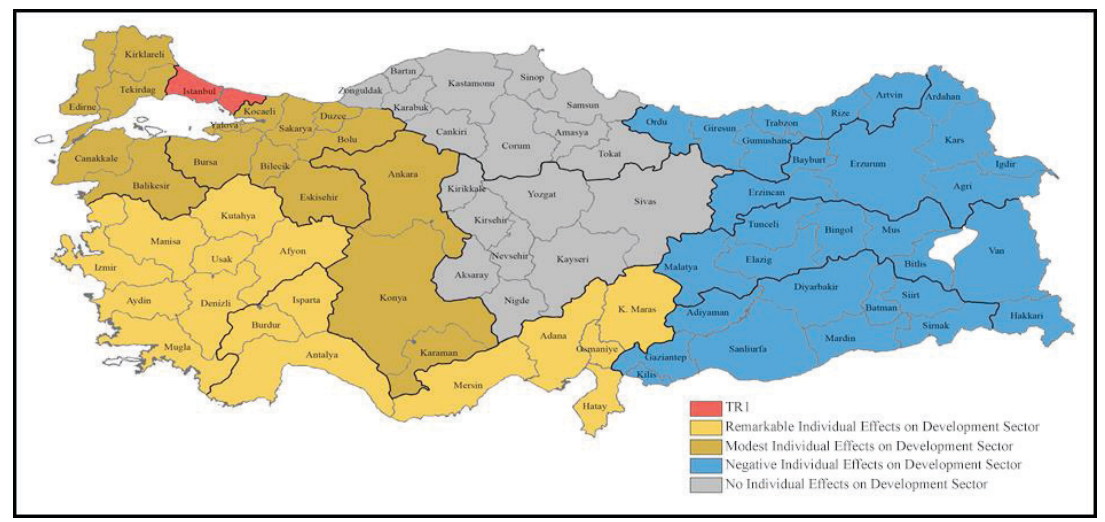

Figure I: Residuals map: The impact of household disposable income on residential building permits in NUTSI level regions (Authors) 


\subsection{NUTS2 Level Summary}

The NUTS2 level model covers 26 regions and draws on data from the 2004-2011 periods. Again the dependent variable is residential building permits, while the independent variable is gross value added (GVA). The period is restricted between 2006 and 2011 since the GVA data ended in 2011 when this research was started. As with the NUTS1 level model, the natural logarithm of the variables is computed for use in the models. The variables are shown to be stable on the basis of unit root test results and, consequently a time variable is included in the estimation procedure (see Equation 2).

$$
\sum_{i=1}^{26} \sum_{t=2004}^{2011} y_{i, t}=A+B 1 \sum_{i=1}^{26} \sum_{t=2004}^{2011} X_{i, t}+B 2 y_{e a r}+u_{i, t}
$$

\section{Equation 2: NUTS2 level model}

Again, our two models are estimated, one with and one without the regional dummies (Table 4-5). The model without region dummies shows that the time trend has a significant and positive impact on residential building permits at $10 \%$ level ( $\mathrm{p}$ value is 0.64 ). This suggests that there has been a systematic increase in activity over time that is not explained by the GVA. The model also shows that there is a significant and positive relation between GVA and residential building permits at all significance levels. All else equal, a 1\% increase in GVA would increase the residential building permits by $0.42 \%$. It might be argued, as theory would suggest, that economic productivity of a region has a strong impact on local housing sector development.

Table 4: NUTS2 level model estimation-without dummies

\begin{tabular}{|l|l|l|l|l|lr|}
\hline Logpermit & Coef. & Std. Err. & $\mathbf{Z}$ & P>IzI & [95\% Conf. Interval] \\
\hline loggva & .9966056 & .0689041 & 14.46 & 0.000 & .861556 & 1.131655 \\
year & .0074441 & .016095 & 0.46 & 0.644 & -.0241015 & .0389897 \\
cons & -24.26837 & 31.73957 & -0.76 & 0.445 & -86.47679 & 37.94005 \\
\hline
\end{tabular}

Notes: Cross-sectional time-series FGLS regression; Coefficients: Generalized Least Squares; Panels: Heteroskedastic; Correlation: Common AR(1) coefficient for all panels (0.6332); Estimated Covariances: 26; Estimated Autocorrelations: 1; Estimated Coefficients: 3; Number of obs $=208$; Number of groups $=26$; Time periods $=8$; Wald chi2 (2) $=289.85 ;$ Prob > chi $2=0.0000$ 
Table 5: NUTS2 level model estimation-with dummies

\begin{tabular}{|l|l|l|l|l|lc|}
\hline Logpermit & Coef. & Std. Err. & $\mathbf{z}$ & P>IzI & {$[\mathbf{9 5} \%$ Conf. Interval] } \\
\hline Loggva & 0.395691 & 0.292089 & 1.35 & 0.176 & -0.176792 & 0.968175 \\
Year & 0.071124 & 0.033872 & 2.1 & 0.036 & 0.004738 & 0.137511 \\
TR21 & 0.310769 & 0.704317 & 0.44 & 0.659 & -1.069666 & 1.691204 \\
TR22 & 0.912220 & 0.773995 & 1.18 & 0.239 & -0.604783 & 2.429223 \\
TR31 & 1.108149 & 0.447615 & 2.48 & 0.013 & 0.230841 & 1.985458 \\
TR32 & 1.494956 & 0.618022 & 2.42 & 0.016 & 0.283655 & 2.706258 \\
TR33 & 0.868123 & 0.618476 & 1.4 & 0.16 & -0.344067 & 2.080314 \\
TR41 & 0.490314 & 0.460481 & 1.06 & 0.287 & -0.412213 & 1.392840 \\
TR42 & 0.899483 & 0.470009 & 1.91 & 0.056 & -0.021718 & 1.820683 \\
TR51 & 0.820656 & 0.381866 & 2.15 & 0.032 & 0.072213 & 1.569099 \\
TR52 & 0.383077 & 0.732957 & 0.52 & 0.601 & -1.053492 & 1.819645 \\
TR61 & 0.931552 & 0.604024 & 1.54 & 0.123 & -0.252314 & 2.115417 \\
TR62 & 0.522138 & 0.588127 & 0.89 & 0.375 & -0.630569 & 1.674845 \\
TR63 & 0.318282 & 0.718536 & 0.44 & 0.658 & -1.090024 & 1.726588 \\
TR71 & 0.558918 & 0.860866 & 0.65 & 0.516 & -1.128349 & 2.246184 \\
TR72 & 0.225958 & 0.737821 & 0.31 & 0.759 & -1.220144 & 1.672061 \\
TR81 & -0.765333 & 0.885195 & -0.86 & 0.387 & -2.500282 & 0.969616 \\
TR82 & -0.049861 & 1.059588 & -0.05 & 0.962 & -2.126615 & 2.026892 \\
TR83 & 0.425681 & 0.690643 & 0.62 & 0.538 & -0.927954 & 1.779316 \\
TR90 & 0.029853 & 0.708469 & 0.04 & 0.966 & -1.358721 & 1.418427 \\
TRA1 & -0.633749 & 1.014720 & -0.62 & 0.532 & -2.622565 & 1.355066 \\
TRA2 & -1.425479 & 1.103113 & -1.29 & 0.196 & -3.587541 & 0.736583 \\
TRB1 & -0.128994 & 0.891335 & -0.14 & 0.885 & -1.875979 & 1.617992 \\
TRB2 & -1.338990 & 0.968821 & -1.38 & 0.167 & -3.237844 & 0.559864 \\
TRC1 & -0.673274 & 0.847046 & -0.79 & 0.427 & -2.333453 & 0.986906 \\
TRC2 & -1.175569 & 0.825811 & -1.42 & 0.155 & -2.794129 & 0.442992 \\
TRC3 & -1.051721 & 0.943224 & -1.12 & 0.265 & -2.900407 & 0.796964 \\
cons & -142.217900 & 62.500720 & -2.28 & 0.023 & -264.717100 & -19.718760 \\
\hline
\end{tabular}

Notes: Estimated Covariances: 26; Estimated Autocorrelations: 1; Estimated Coefficients: 28; Number of obs= 208; Number of groups = 26; Time periods $=8$; Wald chi2 $(2)=4239.54 ;$ Prob $>$ chi2 $=0.0000$

The strength of each the impact of each NUTS2 region on residential building permits is revealed by the regional dummies. The model shows that 4 out of 26 NUTS2 regions have significant strong positive impact on residential building permits relative to Istanbul (Table 5). Gross value added in TR32 (Aydın, Denizli, Muğla) region has the strongest impact on housing development. This is followed by TR31 (İzmir) and TR42 (Bolu, Kocaeli, Sakarya, Düzce, Yalova) regions. This result is consistent with the NUTS1 level estimation result. Therefore, it appears that average disposable income and gross value added are strongly related to housing sector activity; with the strength of impact varying in scale locally (Figure 2). However, some regions effect on sector development different from the aggregate level analysis. For instance, although the income effect on the sector development in regions TR22, TR41, TR51, TR52, TR61, TR61 and TR33 are remarkable, those have no individual effect on sector development by GVA relative to Istanbul. This may show that 
lower scale analysis reflect the uneven development of focused sector more obviously than that aggregate analysis.

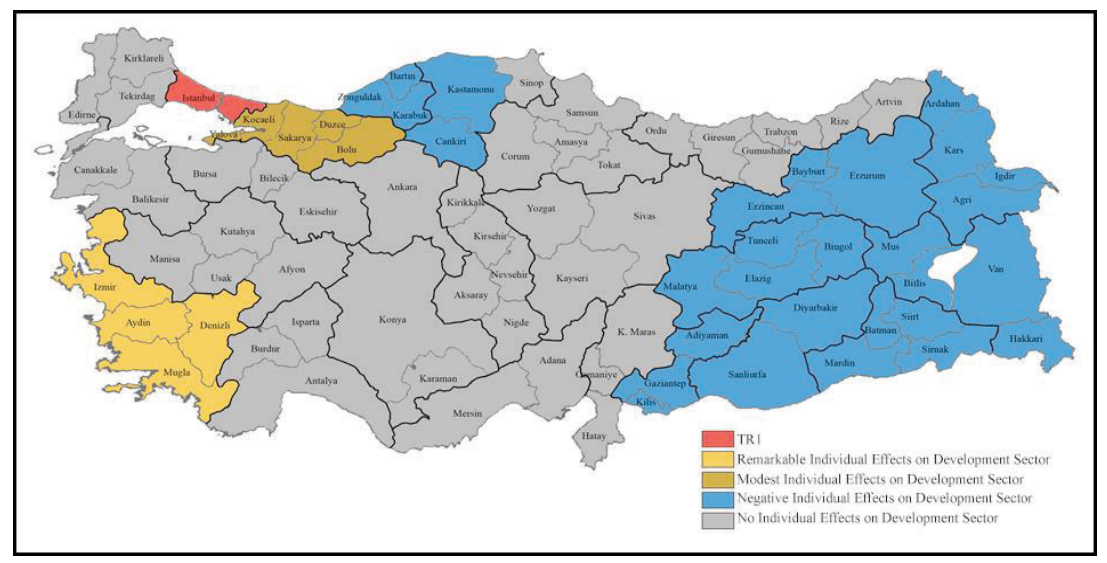

Figure 2: Residuals map: The impact of gross value added on residential building permits in NUTS2 level regions (Authors)

\subsection{NUTS3 Level Summary}

The NUTS3 level models cover 81 provinces and draw on data from 2007-2014. The period is restricted between 2007 and 2014, since during the research period the data for all 81 provinces (cities) were available together at these years. The dependent variable is once again residential building permits, and the independent variables are total public expenditure, population, and total bank credits. The natural logarithm of the variables are used in the modelling procedure. The variables are shown to stable on the basis of unit root test results, and again, a time variable is included in the model estimation (see Equation 3).

$$
\begin{gathered}
y_{i, t}=A+B 1 \sum_{i=1}^{81} \sum_{t=2007}^{2014} X 1_{i, t}+B 2 \sum_{i=1}^{81} \sum_{t=2007}^{2014} X 2_{i, t}+B 3 \sum_{i=1}^{81} \sum_{t=2007}^{2014} X 3_{i, t}+ \\
B 4 \sum_{i=1}^{81} \sum_{t=2007}^{2014} X 4_{i, t}+B 5 d_{i}+u_{i, t} \\
d_{i}=1 \text { for each city } i .
\end{gathered}
$$

\section{Equation 3: NUTS3 level model}

The model results indicate that total public expenditure and total bank credits are statistically significant and have positive effects on residential building permits (see Appendix 1). All else equal, 
a $10 \%$ increase in total public expenditures would increase the residential building permit numbers by $4.4 \%$ in provinces. Similarly, all else equal, a $10 \%$ increase in total bank credits would increase the residential building permit numbers by $1.7 \%$ across the provinces. The models do not show any significant relationship between population change and residential building permits. The graph that shows relationship between population and residential building permits on Appendix 2 verifies the analysis results clearly (see Appendix 2). This weakens the general acceptance of the impact of population growth on housing development activity. Housing need caused by population growth has to be taken together with consumption pattern as well as capital savings of population ${ }^{31}$.

With the exception of just two provinces, all others show significant negative individual effects on housing development in contrast with İstanbul (see Appendix 1). The two insignificant provinces (İzmir and Ankara) can be interpreted as having a similar impact on residential building permits as Istanbul does. All of the other provinces act as a relative drag on activity. This is not entirely surprising and might readily be explained by the virtuous benefits that Istanbul, Izmir and Ankara experience as centres of investment activity and as the focal point for public sector investment and pro-development policy interventions ${ }^{32}$. This may also show that housing construction sector has a polarized development pattern across the country, and, Istanbul, Ankara and İzmir are three poles of the development activity.

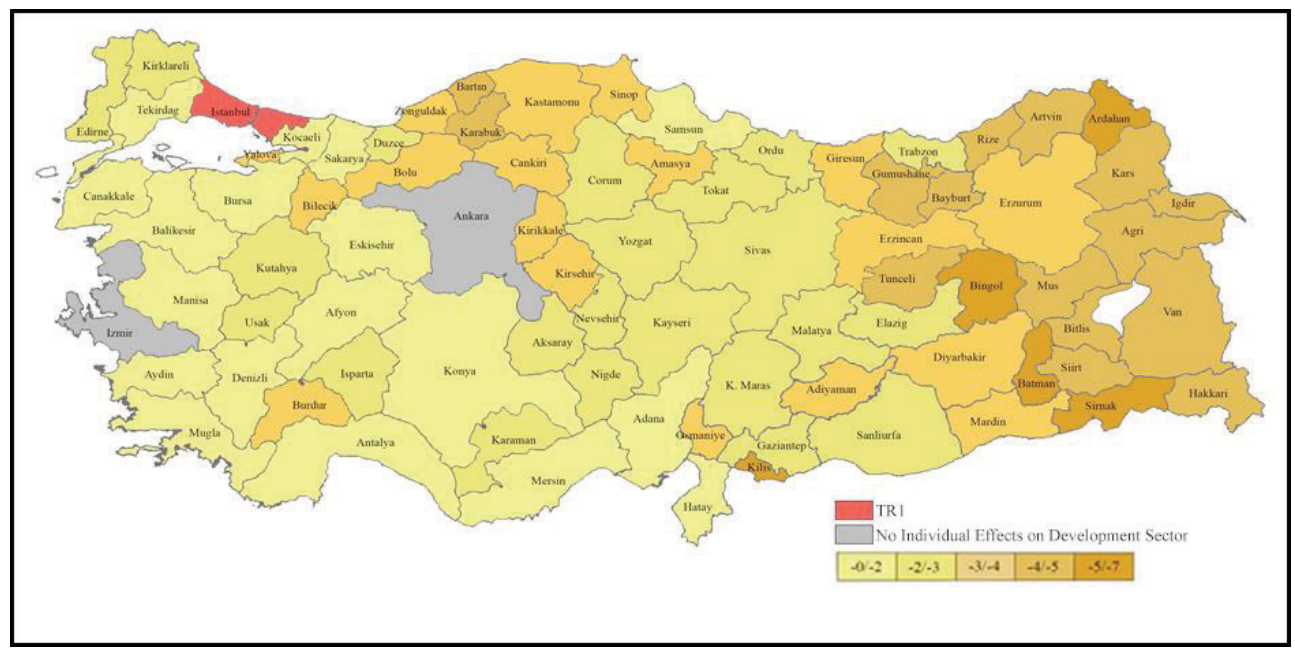

Figure 3: Residuals map: Province level effect on residential building permits (Authors)

Provinces (e.g Iğdır, Şırnak, Batman, Bayburt, Ardahan, Kilis) that display the largest negative impacts on housing development activity get the lowest share from total public spending, and

31 MALPEZZI, S. \& Mayo, S.K. (1987). The Demand for Housing in Developing Countries: Empirical Estimates from Household Data, Economic Development and Cultural Change, 35(4), 687-721, https://doi.org/10.1086/451618

32 ALKAY, E., Watkins, C. \& Keskin, B. (2018). Explaining Spatial Variation in Housing Construction Activity in Turkey, International Journal of Strategic Property Management, 22(2), 119-130, https://doi.org/10.3846/ijspm.2018.443 
they are also among the provinces that have seen the lowest level of bank credits issued. Those provinces all exhibit a negative impact on development sector activity at all geographical scales. Moreover, this lowest scale spatial analysis show the differences within the same region. For instance, at NUTS1 and NUTS2 level analysis, TRA (TRA1/TRA2), TRB (TRB1/TRB2), TRC (TRC1/TRC2/TRC3) regions has negative individual effect on sector development. Although all provinces in these regions have still negative effect on sector development, some of these provinces' negative effect is smaller while the others are largest.

\subsection{Overview of the Model Results}

At the general level, the analysis provides clear evidence of a strong relationship between local level economic indicators and residential building permit numbers. The analysis of spatial differences adds to the explanatory power of the aggregate analysis. The economic performance of regions affects the residential building permits directly. There are also systematic differences between local and regional housebuilding activity and economic fundamentals. This appears to reflect the influence of a range of institutional factors including the preferences of the investment industry, the impact of public sector infrastructure investment, and the effects of the local planning regime and public policy interventions.

From the spatial perspective, in general the weaker the economic growth, even if it is slightly positive, the weaker the impact on housing development. Thus, the strongest levels of economic growth lead to strongest the impact on the housing development activity. The development potential of the housing is high in regions, where the impact of economic indicators on residential building permits is modest, but any negative change in economic conditions might be hard to overcome.

Unsurprisingly, the main cities in Turkey deviate from normal patterns. Istanbul, Izmir and Ankara appear to have experienced levels of housing development in excess of that which might be readily explained by economic performance. The NUTS3 and NUTS2 level analysis, in particular, illustrate the sharp contrast between Istanbul and other regions and provinces.

\section{Conclusions}

This paper seeks to analyse the relationship between economic indicators and housing construction activity in Turkey. The analysis is based on statistical models developed at three different spatial scales. Taken together, these models provide evidence of the spatial and temporal drivers of housing construction activity, as measured by residential building permits granted, within Turkey during the study period between 2004 and 2014.

The analysis shows that the Turkish housing construction sector has experienced significant expansion over the period but that this growth in activity has been volatile over time and has 
been highly variable across space. Some of the patterns observed have clearly been driven by national and economic indicators with, typically, areas with weaker economic growth exhibiting lower levels of activity. The models, however, explain relative modest levels of the change in residential building permit levels. This may, in small part, be a result of the imperfect nature of the dependent variable. More likely, however, this is a consequence of the very significant role that has been played by institutional change and by conditions that have been created by government investment and by local and national public policy interventions and proactive planning activities.

The analysis of the paper developed in three different periods and available data in different NUTS levels, which made difficult to comparing analysis result. The availability of valid, reliable and consistent data is important both in modelling the relationship between housing construction sector and economic development and in comparing nationwide spatial differences.

Equation 1 and 2 show that housing construction sector's future depends largely on the success of national government in stimulating economic growth. Therefore, both national and local policies should consider about the resilience of the housing construction sector in fluctuations in the economy. Aggregate level analysis results are parallel with Bielsa and Duarte $(2011)^{33}$ and Su et al. (2010) ${ }^{34}$ that GVA has strong impact on housing construction sector development, and, large scale public investment potentially stimulate socio-economic development and, to the extent, housing construction sector development. Bank credits availability has dominant effect on sector development as exposed by Thom $(1985)^{35}$.

Analysis results reflect that aggregate level analysis cannot draw spatial differences detailed regarding the relationship between economic indicators and housing construction sector development. Lower spatial scale analysis disclosures spatial differences in detailed and provide a ground for developing locally consistent policies. Uneven spatial development of housing construction sector is also needed to be analysed to the extent of lags in the price and supply adjustment. This would be clarified agenda setting for policy, further, directed establishing area based policy actions.

The findings from this paper pose some interesting further questions. First, it would be interesting to develop a greater understanding of the divergence between market fundamentals and housing construction activity in key economic centres, such as Istanbul, is typical of what might be observed in other emerging markets where housing construction has also taken on a critical role in economic development strategies. There is clearly a need to develop a better understanding of the role of public policy in steering and shaping market outcomes (Adams and Watkins, 2015).

33 BIELSA, J., Duarte, R. (2011). Size and linkages of the Spanish construction industry: key sector or deformation of the economy?, Cambridge Journal of Economics, 35, 317-334, doi:10.1093/cje/beq016

34 SU, C-K., Lin, C-Y., Wang, M-T. (2010). Taiwanese construction sector in a growing 'maturity' economy, 1964-1999, Construction Management and Economics, 21(7), 719-728, DOI: 10.1080/014.461.9032000064082

35 THOM, R. (1985). The Relationship between Housing Starts and Mortgage Availability, The Review of Economics and Statistics, 67(4), 693-696. 
Second, it would be interesting to explore the extent to which the extreme spatial variations in construction activity identified are specific to this study area. Again, there is some evidence to suggest that the extent of uneven spatial development observed here might be characteristic of emerging economies but the research base is very limited.

Acknowledgement: This paper is based on a part of the research project that funded by British Academy (AF140121).

\section{References}

ADAMS, D and Watkins, C (2015) The Value of Planning, London: RTPI.

ALKAY, E., Watkins, C. \& Keskin, B. (2018). Explaining Spatial Variation in Housing Construction Activity in Turkey, International Journal of Strategic Property Management, 22(2), 119-130, https://doi. org/10.3846/ijspm.2018.443

BAHÇEKAPILI, C. (2015). Türkiye Ekonomisinde 2011 Sonrası Sınırlı Büyümenin Nedenleri Üzerine Bir Analiz, Marmara Üniversitesi, İ.İ.B. Dergisi, Cilt XXXVII, Sayı I, 111-124.

BIELSA, J., Duarte, R. (2011). Size and linkages of Spanish construction industry: key sector or deformation of the economy?, Cambridge Journal of Economics, 35, 317-334.

BLAYSE, A.M., Manley, K. (2004). Key influences on construction innovation, Construction Innovation, 4, 143-154.

BON, R., Birgönül, T. \& Özdoğan, İ. (1999). An input-output analysis of the Turkish construction sector, 1973-1990: a note, Construction Management and Economics, 17(5), 543-551.

BRAMLEY, G., Watkins, C. (1995) Steering the Housing Market, Bristol, Policy Press.

CHANG, T., Nieh, C.C. (2004). A note on testing the causal link between construction activity and economic growth in Taiwan, Journal of Asian Economics, 15, 591-598.

CHOW, G.C. (1993). Capital formation and economic growth in China, The Quarterly Journal of Economics, 108(3), 809-842.

ELINWA, A.U., Joshua, M. (2001). Time-overrun factors in Nigerian construction industry, Journal of Construction Engineering and Management, 127(5), 419-425.

EWING, B.T., Wang, Y. (2005). Single housing starts and macroeconomic activity: an application of generalized impulse response analysis, Applied Economic Letters, 12, 187-190.

GIANG, D.T.H., Pheng, L.S. (2011). Role of construction in economic development: Review of key concepts in the past 40 years, Habitat International, 35, 118-125.

HENNEBERRY, J., McGough, T., Mouzakis, F (2005). "Estimating the Impact of Planning on Commercial Property Markets" in Adams, D, Watkins, C and White, M (Eds) Planning, Public Policy and Property Markets, Oxford: Blackwells

HUANG, D.S. (1973). Short-Run Instability in Single-Family Housing Starts, Journal of the American Statistical Association, 68(344), 788-792.

ILHAN, B., Yaman, H. (2011). A comparative input-output analysis of the construction sector in Turkey and EU countries, Engineering, Construction and Architectural Management, 18(3), 248-265.

JENSEN, J.S., Gottlieb, S.C., Thuesen, C.L. (2011). Construction sector development: frames and governance responses, Building Research and Information, 39(6), 665-667.

KARAHASAN, B.C. (2015). Regional Inequalities in Turkey: Post 2001 Era, Marmara Üniversitesi İ.İ.B. Dergisi, Cilt XXXVII, Sayı I, 125-147. 
KEOGH, G., D’Archy, E. (1999). Property Market Efficiency: An Institutional Economics Perspective, Urban Studies, 36(13), 2401-2414.

KOFOWOROLA, O.F., Gheewala, S. (2008). An input-output analysis of Thailand construction sector, Construction Management and Economics, 26, 1227-1240.

MAISEL, S.J. (1963). A Theory of Fluctuations in Residential Construction Starts, The American Economic Review, 53(3), 359-383.

MALLICK, H. \& Mahalik, M.K. (2010). Constructing the economy: the role of construction sector in India's growth, Journal of Real Estate Finance Economy, 40, 368-384.

MALPEZZI, S. \& Mayo, S.K. (1987). The Demand for Housing in Developing Countries: Empirical Estimates from Household Data, Economic Development and Cultural Change, 35(4), 687-721, https://doi.org/10.1086/451618

MAYER, C.J., Tsuriel Somerville, C. (2000). Land use regulation and new construction, Regional Science and Urban Economics, 30, 639-662.

MAYO, R.R., Liu, G. (1995). Reform agenda of Chinese construction industry, Journal of Construction Engineering and Management, 121(1), 80-85.

OFORI, G. (1994). Formulating a long-term strategy for developing the construction industry of Singapore, Construction Management and Economics, 12, 219-231.

OFORI, G. (2001). Indicators for measuring construction industry development in developing countries, Building Research and Information, 29(1), 40-50.

ÖNER, M.A., Sarıtaş, Ö. (2005). A systems approach to policy analysis and development planning: Construction sector in the Turkish 5-year development plans, Technological Forecasting \& Social Change, 72, 886-911.

OZKAN, F., Ozkan, O., Gunduz, M. (2012). Causal relationship between construction investment policy and economic growth in Turkey, Technological Forecasting \& Social Change, 79, 362-370.

PIERDZIOCH, C., Rülke, J.C., Stadmann, G. (2012). Housing Starts in Canada, Japan, and the United States: Do Forecasters Herd?, The Journal of Real Estate Finance and Economics, 45(3), 754-773.

PIETROFORTE, R., Bon, R. (1995). An input-output analysis of the Italian construction sector, 1959-1998, Construction Management and Economics, 13, 253-262.

PIETROFORTE, R., Gregori, T. (2003). An input-output analysis of the construction sector in highlydeveloped economies, Construction Management and Economics, 21, 319-327.

POLENSKE, K.R., Sivitanides, P. (1990). Linkages in the construction sector, The Annals of Regional Science, 24, 147-161.

POSNER, R. (1998). Creating a legal framework for economic development, The World Bank Research Observer, 13(1), 1-11.

PURI, A.K., Van Lierop, J. (1988). Forcasting housing starts, International Journal of Forecasting, 4(1), 125134.

RAHMAN, M., Mustafa, M. (1997). Growth in US housing starts, real consumer depth, real GDP and the long-term real interest rate: a vector cointegration analysis, Applied Economic Letters, 4, 757-759.

RUDDOCK, L., Lopes, J. (2006). The construction sector and economic development: the 'Bon curve', Construction Management and Economics, 24, 717-723.

RUDDOCK, L., Ruddock, S. (2009). Reassessing productivity in the construction sector to reflect hidden innovation and the knowledge economy, Construction Management and Economics, 27, 871-879. 
SLAUGHTER, E.S. (1998). Models of construction innovation, Journal of Construction Engineering and Management, 124(3), 226-231.

SONG, Y., Liu, C., Langston, C. (2006). Linkage measures of the construction sector using the hypothetical extraction method, Construction Management and Economics, 24, 579-589.

SU, C-K., Lin, C-Y., Wang, M-T. (2003). Taiwanese construction sector in a growing 'maturity' economy, 1964-1999. Construction Management and Economics, 21, 7, 719-728.

STEVENSON, J.R., Emrich, C.T., Mitchell, J.T., Cutter, S.L. (2010). Using Building Permits to Monitor Disaster Recovery: A Spatio-Temporal Case Study of Coastal Mississippi Following Hurricane Katrina, Cartography and Geographic Information Science, 37(1), 57-68.

TBB (Türkiye Bankalar Birliği), (2015). İstatistiki Raporlar, İl Bazında Kredi ve Mevduat Durumu, Temmuz 2015, www.tbb.gov.tr

THOM, R. (1985). The Relationship between Housing Starts and Mortgage Availability, The Review of Economics and Statistics, 67(4), 693-696.

TMB (Turkiye Muteahhitler Birligi) (2015). Insaat Sektoru Analizi Bulteni, 2015/Temmuz, Ankara.

TOPEL, R., Rosen, S. (1988). Housing investment in the United States, Journal of Political Economy, 96(4), 718-740.

TUIK (Türkiye İstatistik Kurumu), (2014a). Illere Gore Insaat Izin Istatistikleri, Haziran 2014 (Veri TUIK den satin alinmistir).

TUIK (Türkiye İstatistik Kurumu), (2014b). İstatistiksel Tablolar, Ylllara Göre İl Nüfusları, http://tuik.gov. tr/PreTablo.do?alt_id=1059

TUIK (Türkiye İstatistik Kurumu), (2015a). İstatistiksel Tablolar, Üretim Yöntemi ile GSYH, Sabit Fiyatlarla GSYH, Faaliyet Kollarına Göre GSYH, Temmuz 2015, http://www.tuik.gov.tr/PreTabloArama.do

TUIK (Türkiye İstatistik Kurumu), (2015b). İstatistiksel Tablolar, Gelir İstatistikleri, Temmuz 2015, http:// www.tuik.gov.tr/PreTabloArama.do

TUIK (Türkiye İstatistik Kurumu), (2015c). İstatistiksel Tablolar, Bölgesel Hesaplar, Bölgesel Gayrisafi Katma Değer, Temmuz 2015, http://www.tuik.gov.tr/PreTabloArama.do

WELLS, J., Wall, D. (2003). The expansion of employment opportunities in the building construction sector in the context of structural adjustment: some evidence from Kenya and Tanzania, Habitat International, 27, 325-337.

WELLS, J. (2001). Construction and capital formation in less developed economies: unravelling the informal sector in an African city, Construction Management and Economics, 19(3), 267-274.

WHYTE, J. (2003). Innovation and users: virtual reality in the construction sector, Construction Management and Economics, 21, 565-572.

WONG, J.M.W., Ng, S.T., Chan, A.P.C. (2010). Strategic planning for the sustainable development of the construction industry in Hong Kong, Habitat International, 34, 256-263. 


\section{Appendix I}

Table: NUTS3 level model estimation-with dummies

\begin{tabular}{|c|c|c|c|c|c|c|c|}
\hline & Logpermit & Coef. & Std. Err. & $\mathbf{Z}$ & P>IzI & \multicolumn{2}{|c|}{ [95\% Conf. Interval] } \\
\hline & dlogcredit & 0,427919 & 0,136483 & 3,14 & 0,002 & 0,160417 & 0,695422 \\
\hline & dloggovspnd & 1,058277 & 0,320946 & 3,3 & 0,001 & 0,429235 & 1,687318 \\
\hline & dlogpop & $-1,21117$ & 1,123195 & $-1,08$ & 0,281 & $-3,41259$ & 0,990254 \\
\hline 1 & Adana & $-1,36818$ & 0,179335 & $-7,63$ & 0,00 & $-1,71967$ & $-1,01669$ \\
\hline 2 & Adıyaman & $-3,32388$ & 0,193843 & $-17,15$ & 0,00 & $-3,70381$ & $-2,94395$ \\
\hline 3 & Afyon & $-1,79229$ & 0,192996 & $-9,29$ & 0,00 & $-2,17056$ & $-1,41403$ \\
\hline 4 & Ăğrı & $-4,04182$ & 0,183013 & $-22,08$ & 0,00 & $-4,40052$ & $-3,68312$ \\
\hline 5 & Amasya & $-3,14419$ & 0,194589 & $-16,16$ & 0,00 & $-3,52558$ & $-2,76281$ \\
\hline 6 & Ankara & $-0,26528$ & 0,175277 & $-1,51$ & 0,13 & $-0,60882$ & 0,078258 \\
\hline 7 & Antalya & $-0,75288$ & 0,184677 & $-4,08$ & 0,00 & $-1,11484$ & $-0,39092$ \\
\hline 8 & Artvin & $-4,28279$ & 0,223469 & $-19,17$ & 0,00 & $-4,72078$ & $-3,8448$ \\
\hline 9 & Aydın & $-1,17269$ & 0,181825 & $-6,45$ & 0,00 & $-1,52906$ & $-0,81632$ \\
\hline 10 & Balıkesir & $-0,96422$ & 0,169226 & $-5,7$ & 0,00 & $-1,2959$ & $-0,63254$ \\
\hline 11 & Bilecik & $-3,16794$ & 0,230123 & $-13,77$ & 0,00 & $-3,61898$ & $-2,71691$ \\
\hline 12 & Bingöl & $-5,30814$ & 0,340019 & $-15,61$ & 0,00 & $-5,97457$ & $-4,64172$ \\
\hline 13 & Bitlis & $-4,14761$ & 0,205486 & $-20,18$ & 0,00 & $-4,55035$ & $-3,74486$ \\
\hline 14 & Bolu & $-3,04555$ & 0,203214 & $-14,99$ & 0,00 & $-3,44384$ & $-2,64725$ \\
\hline 15 & Burdur & $-3,04856$ & 0,187104 & $-16,29$ & 0,00 & $-3,41528$ & $-2,68185$ \\
\hline 16 & Bursa & $-0,83723$ & 0,176318 & $-4,75$ & 0,00 & $-1,18281$ & $-0,49165$ \\
\hline 17 & Çanakkale & $-1,90194$ & 0,202329 & $-9,4$ & 0,00 & $-2,2985$ & $-1,50538$ \\
\hline 18 & Çankırı & $-3,25386$ & 0,177935 & $-18,29$ & 0,00 & $-3,60261$ & $-2,90512$ \\
\hline 19 & Çorum & $-2,34794$ & 0,248207 & $-9,46$ & 0,00 & $-2,83441$ & $-1,86146$ \\
\hline 20 & Denizli & $-1,3904$ & 0,171282 & $-8,12$ & 0,00 & $-1,72611$ & $-1,05469$ \\
\hline 21 & Diyarbakır & $-3,36362$ & 0,200036 & $-16,82$ & 0,00 & $-3,75569$ & $-2,97156$ \\
\hline 22 & Edirne & $-2,20009$ & 0,245987 & $-8,94$ & 0,00 & $-2,68222$ & $-1,71797$ \\
\hline 23 & Elazig & $-2,41636$ & 0,217119 & $-11,13$ & 0,00 & $-2,84191$ & $-1,99082$ \\
\hline 24 & Erzincan & $-3,11617$ & 0,197654 & $-15,77$ & 0,00 & $-3,50357$ & $-2,72877$ \\
\hline 25 & Erzurum & $-3,22583$ & 0,195036 & $-16,54$ & 0,00 & $-3,6081$ & $-2,84357$ \\
\hline 26 & Eskisehir & $-1,40828$ & 0,190226 & $-7,4$ & 0,00 & $-1,78112$ & $-1,03544$ \\
\hline 27 & Gaziantep & $-2,76095$ & 0,212021 & $-13,02$ & 0,00 & $-3,1765$ & $-2,3454$ \\
\hline 28 & Giresun & $-3,16959$ & 0,197148 & $-16,08$ & 0,00 & $-3,55599$ & $-2,78319$ \\
\hline 29 & Gumushane & $-4,05668$ & 0,22104 & $-18,35$ & 0,00 & $-4,48991$ & $-3,62345$ \\
\hline 30 & Hakkari & $-4,69172$ & 0,225272 & $-20,83$ & 0,00 & $-5,13324$ & $-4,25019$ \\
\hline
\end{tabular}




\begin{tabular}{|c|c|c|c|c|c|c|c|}
\hline 31 & Hatay & $-1,57421$ & 0,174774 & $-9,01$ & 0,00 & $-1,91676$ & $-1,23166$ \\
\hline 32 & Isparta & $-2,42238$ & 0,17708 & $-13,68$ & 0,00 & $-2,76945$ & $-2,07531$ \\
\hline 33 & Icel & $-1,34866$ & 0,172306 & $-7,83$ & 0,00 & $-1,68637$ & $-1,01095$ \\
\hline 35 & Izmir & 0,0265 & 0,185965 & 0,14 & 0,887 & $-0,33798$ & 0,390984 \\
\hline 36 & Kars & $-4,67484$ & 0,184622 & $-25,32$ & 0,00 & $-5,03669$ & $-4,31298$ \\
\hline 37 & Kastamonu & $-3,12494$ & 0,195173 & $-16,01$ & 0,00 & $-3,50747$ & $-2,74241$ \\
\hline 38 & Kayseri & $-2,0033$ & 0,18152 & $-11,04$ & 0,00 & $-2,35907$ & $-1,64753$ \\
\hline 39 & Kirklareli & $-2,82702$ & 0,245165 & $-11,53$ & 0,00 & $-3,30754$ & $-2,34651$ \\
\hline 40 & Kirsehir & $-3,06901$ & 0,211821 & $-14,49$ & 0,00 & $-3,48417$ & $-2,65385$ \\
\hline 41 & Kocaeli & $-0,95607$ & 0,19112 & -5 & 0,00 & $-1,33066$ & $-0,58149$ \\
\hline 42 & Konya & $-1,20652$ & 0,180243 & $-6,69$ & 0,00 & $-1,55979$ & $-0,85325$ \\
\hline 43 & Kutahya & $-2,30907$ & 0,201901 & $-11,44$ & 0,00 & $-2,70479$ & $-1,91335$ \\
\hline 44 & Malatya & $-2,56832$ & 0,176568 & $-14,55$ & 0,00 & $-2,91438$ & $-2,22225$ \\
\hline 45 & Manisa & $-1,18152$ & 0,174367 & $-6,78$ & 0,00 & $-1,52328$ & $-0,83977$ \\
\hline 46 & Kahramanmaras & $-2,39583$ & 0,185127 & $-12,94$ & 0,00 & $-2,75868$ & $-2,03299$ \\
\hline 47 & Mardin & $-3,19744$ & 0,178671 & $-17,9$ & 0,00 & $-3,54763$ & $-2,84725$ \\
\hline 48 & Mugla & $-0,7093$ & 0,166066 & $-4,27$ & 0,00 & $-1,03479$ & $-0,38382$ \\
\hline 49 & Mus & $-4,90602$ & 0,357678 & $-13,72$ & 0,00 & $-5,60705$ & $-4,20498$ \\
\hline 50 & Nevsehir & $-2,69041$ & 0,199123 & $-13,51$ & 0,00 & $-3,08069$ & $-2,30014$ \\
\hline 51 & Nigde & $-2,5358$ & 0,196577 & $-12,9$ & 0,00 & $-2,92108$ & $-2,15051$ \\
\hline 52 & Ordu & $-2,50871$ & 0,169875 & $-14,77$ & 0,00 & $-2,84166$ & $-2,17576$ \\
\hline 53 & Rize & $-4,7591$ & 0,166794 & $-28,53$ & 0,00 & $-5,08601$ & $-4,43219$ \\
\hline 54 & Sakarya & $-1,42952$ & 0,177392 & $-8,06$ & 0,00 & $-1,7772$ & $-1,08184$ \\
\hline 55 & Samsun & $-1,77982$ & 0,175214 & $-10,16$ & 0,00 & $-2,12323$ & $-1,43641$ \\
\hline 56 & Siirt & $-4,44926$ & 0,194348 & $-22,89$ & 0,00 & $-4,83017$ & $-4,06834$ \\
\hline 57 & Sinop & $-3,27646$ & 0,198176 & $-16,53$ & 0,00 & $-3,66488$ & $-2,88805$ \\
\hline 58 & Sivas & $-2,6125$ & 0,212193 & $-12,31$ & 0,00 & $-3,02839$ & $-2,19661$ \\
\hline 59 & Tekirdag & $-1,77576$ & 0,179892 & $-9,87$ & 0,00 & $-2,12834$ & $-1,42317$ \\
\hline 60 & Tokat & $-2,91157$ & 0,212826 & $-13,68$ & 0,00 & $-3,3287$ & $-2,49444$ \\
\hline 61 & Trabzon & $-2,10617$ & 0,174561 & $-12,07$ & 0,00 & $-2,4483$ & $-1,76403$ \\
\hline 62 & Tunceli & $-4,46395$ & 0,221127 & $-20,19$ & 0,00 & $-4,89735$ & $-4,03055$ \\
\hline 63 & Sanliurfa & $-2,80365$ & 0,178793 & $-15,68$ & 0,00 & $-3,15408$ & $-2,45322$ \\
\hline 64 & Usak & $-2,60177$ & 0,178881 & $-14,54$ & 0,00 & $-2,95237$ & $-2,25117$ \\
\hline 65 & Van & $-4,58267$ & 0,25509 & $-17,96$ & 0,00 & $-5,08263$ & $-4,0827$ \\
\hline 66 & Yozgat & $-2,8582$ & 0,224398 & $-12,74$ & 0,00 & $-3,29801$ & $-2,41839$ \\
\hline 67 & Zonguldak & $-3,17922$ & 0,209514 & $-15,17$ & 0,00 & $-3,58986$ & $-2,76858$ \\
\hline 68 & Aksaray & $-2,80148$ & 0,195864 & $-14,3$ & 0,00 & $-3,18537$ & $-2,4176$ \\
\hline 69 & Bayburt & $-4,96778$ & 0,228517 & $-21,74$ & 0,00 & $-5,41566$ & $-4,51989$ \\
\hline
\end{tabular}




\begin{tabular}{|l|l|l|l|l|l|ll|}
\hline $\mathbf{7 0}$ & Karaman & $-2,94367$ & 0,212754 & $-13,84$ & 0,00 & $-3,36066$ & $-2,52668$ \\
$\mathbf{7 1}$ & Kirikkale & $-3,56697$ & 0,192546 & $-18,53$ & 0,00 & $-3,94435$ & $-3,18959$ \\
$\mathbf{7 2}$ & Batman & $-6,31621$ & 0,469624 & $-13,45$ & 0,00 & $-7,23666$ & $-5,39577$ \\
$\mathbf{7 3}$ & Sirnak & $-6,4071$ & 0,30577 & $-20,95$ & 0,00 & $-7,0064$ & $-5,8078$ \\
$\mathbf{7 4}$ & Bartin & $-4,21923$ & 0,216621 & $-19,48$ & 0,00 & $-4,6438$ & $-3,79466$ \\
$\mathbf{7 5}$ & Ardahan & $-5,39713$ & 0,245927 & $-21,95$ & 0,00 & $-5,87914$ & $-4,91513$ \\
$\mathbf{7 6}$ & Igdir & $-4,25034$ & 0,433744 & $-9,8$ & 0,00 & $-5,10047$ & $-3,40022$ \\
$\mathbf{7 7}$ & Yalova & $-3,22655$ & 0,265434 & $-12,16$ & 0,00 & $-3,74679$ & $-2,70631$ \\
$\mathbf{7 8}$ & Karabuk & $-4,01779$ & 0,267246 & $-15,03$ & 0,00 & $-4,54158$ & $-3,494$ \\
$\mathbf{7 9}$ & Kilis & $-5,12417$ & 0,550169 & $-9,31$ & 0,00 & $-6,20248$ & $-4,04586$ \\
$\mathbf{8 0}$ & Osmaniye & $-3,37976$ & 0,338201 & $-9,99$ & 0,00 & $-4,04262$ & $-2,7169$ \\
$\mathbf{8 1}$ & Duzce & $-2,96077$ & 0,212974 & $-13,9$ & 0,00 & $-3,37819$ & $-2,54335$ \\
-cons & -cons & 8,581582 & 0,166083 & 51,67 & 0,00 & 8,256066 & 8,907098 \\
\hline
\end{tabular}

Notes: Estimated Covariances: 81; Estimated Autocorrelations: 1; Estimated Coefficients: 84; Number of obs= 566; Number of groups= 81; Time periods=8; Obs per group: min: 6, avg: 6.987654, max: 7; Wald chi2 (2)= 10706.40; Prob $>$ chi2 $=0.0000$

\section{Appendix 2}

Graph: Residential building permits and population

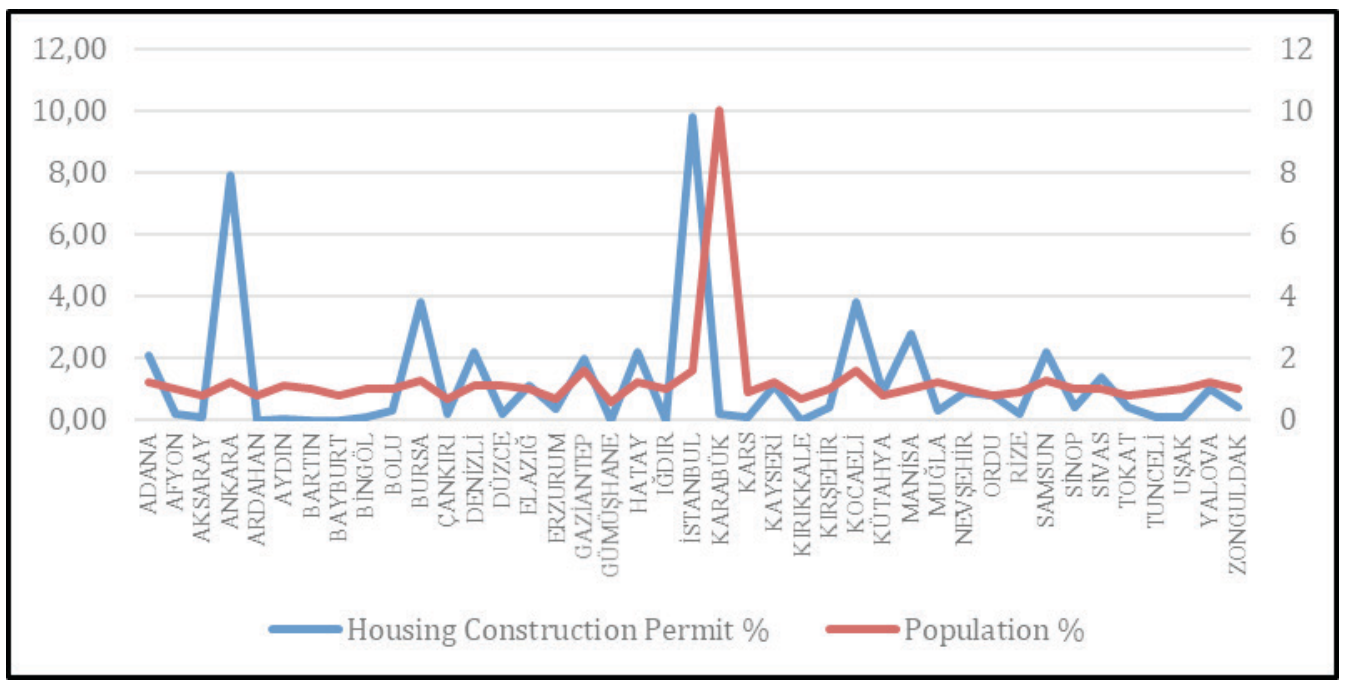

Source: TUIK, 20I4a-b; prepared by authors 